\title{
O ser humano visto pelos seus direitos e os humanos não vistos sem direitos
}

\section{Ângela Molinari Bicalho'}

A palavra humano deriva do latim humanus, que era usada para designar aquilo feito pelo homo, palavra latina de onde veio homem na língua de Camões, hoje também usada para designar tanto homem como mulher ${ }^{2}$. Dessa maneira, humano é aquilo que é feito ou próprio do homem, compreendendo-se este como conceito a abarcar tanto o gênero masculino como o feminino.

No Dicionário de Filosofia de Nicola Abbagnano encontramos os seguintes conceitos de humanidade:

Natureza racional do homem, dotada de dignidade e, portanto, fim para si mesma. Esse é o significado que essa palavra assume na segunda fórmula do imperativo categórico de Kant: "Age de tal maneira que trates a, tanto na tua pessoa quanto na pessoa de qualquer outro, sempre também como fim, nunca somente como meio.

Na pessoa dos homens é objeto do respeito, que, para Kant, é o único sentimento moral.

Disposição à compreensão dos outros ou à simpatia para com eles. Nesse sentido, a melhor definição desse termo foi dada por Kant: "H. (Humanitàt) significa, por um lado, o sentimento universal da simpatia e, por outro, a faculdade de poder comunicar pessoal e universalmente; essas são duas propriedades que, juntas, constituem a sociabilidade própria da $\mathrm{H}$. (Menschheit), graças à qual ela se diferencia do isolamento animal. ${ }^{3}$

O jurista Fábio Konder Comparato, professor titular aposentado da Faculdade de Direito da USP, em sua obra A Afirmação Histórica dos Direitos Humanos, defende que a afirmação histórica dos Direitos Humanos

\footnotetext{
${ }^{1}$ Advogada e aluna do curso de Artes Cênicas.

2 https://www.meusdicionarios.com.br/humano. Acesso em 06/04/2019, às $12: 08$.

${ }^{3}$ ABBAGNANO, Nicola. Dicionário de Filosofia. Trad.: Alfredo Bosi \& Ivone Castilho Benedetti, ed. Martins Fontes, São Paulo, 2007, p. 518.
} 
é a parte mais bela e importante de toda a História: a revelação de que todos os seres humanos, apesar das inúmeras diferenças biológicas e culturais que os distinguem entre si, merecem igual respeito, como únicos entes no mundo capazes de amar, descobrir a verdade e criar a beleza. É o reconhecimento universal de que, em razão dessa radical igualdade, ninguém - nenhum indivíduo, gênero, etnia, classe social, grupo religioso ou nação - pode afirmar-se superior aos demais. ${ }^{4}$

Assim, o conceito de Direitos Humanos parte da ideia de um conjunto de direitos próprio dos humanos, inerentes e inalienáveis desses seres, iguais e imutáveis em qualquer época ou lugar, daí a possibilidade de usar o termo revelação para esses direitos, eis que, inerentes à condição humana, são revelados, descobertos pela noção da Dignidade da Pessoa Humana, conceito lançado pelo Papa Leão XIII em sua clássica Carta Encíclica Rerum Novarum, e expressa em

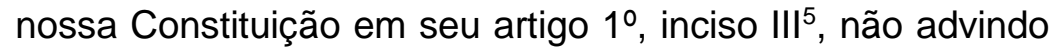
de benesses do Estado ou de um governo em particular.

Dessa forma, o não reconhecimento dos Direitos Humanos por um Estado ou governo não é "mera questão de política normativa interna", já que o não reconhecimento desses direitos atenta contra a Dignidade da Pessoa Humana, e consequentemente a própria Humanidade.

Nessa direção governos são criados pelos homens para a garantia desses direitos, de tal modo que, ao não corresponder a essas aspirações legítimas de seu próprio povo, este pode resistir e instituir um novo governo, para que cumpra com esses ideais humanos essenciais. Nesse sentido já se manifestou o povo norte americano em sua Declaração de Independência:

Consideramos estas verdades como evidentes por si mesmas, que todos os homens são

${ }^{4}$ COMPARATO, Fábio Konder. A Afirmação Histórica dos Direitos Humanos, $5^{\mathrm{a}}$ edição, ed. Saraiva, São Paulo, 2007, p. 1.

${ }^{5}$ Art. $1^{\circ}$ A República Federativa do Brasil, formada pela união indissolúvel dos Estados e Municípios e do Distrito Federal, constitui-se em Estado Democrático de Direito e tem como fundamentos:

(...)

III - a dignidade da pessoa humana; 
criados iguais, dotados pelo Criador de certos direitos inalienáveis, que entre estes estão a vida, a liberdade e a procura da felicidade.

Que a fim de assegurar esses direitos, governos são instituídos entre os homens, derivando seus justos poderes do consentimento dos governados; que, sempre que qualquer forma de governo se torne destrutiva de tais fins, cabe ao povo o direito de alterá-la ou aboli-la e instituir novo governo, baseando-o em tais princípios e organizando-lhe os poderes pela forma que lhe pareça mais conveniente para realizar-Ihe a segurança e a felicidade. ${ }^{6}$

Se humano é o relativo à humanidade, as coisas feitas pelo homem, como um fim em si mesmo, nutrido do sentimento de empatia descrito por Kant, então, por certo, só nos tornamos humano no outro, no convívio com os demais seres humanos nos tornamos humanos. É impossível ser humano sozinho, isolado.

Aristóteles já reconhecia esse caráter coletivo da humanidade ao definir o homem como um animal político, a tal sorte que o homem, isolado, não poderia ser senão um bruto ou um deus ${ }^{7}$, e nenhum dos dois, sob qualquer ótica, seria humano.

Se só somos humanos com o outro, inegável a importância dos Direitos Humanos para a sociedade planetária. Ao não reconhecermos e protegermos os Direitos Humanos de cada um, estamos negando, na essência, a própria Humanidade.

Lamentável que nos dias de hoje esse conceito simples não seja compreendido e ainda por cima manipulado por seres humanos contra outros humanos.

Se só nos tornamos humano com o outro, mediante o contato do outro, como esperar humanidade dos chamados seres invisíveis?

\footnotetext{
${ }^{6}$ Declaração de Independência dos Estados Unidos da América. Disponível em http://www.uel.br/pessoal/jneto/gradua/historia/recdida/declaraindepeEU AHISJNeto.pdf. Acesso em 06/04/2019, às 13:27.

7 BRYCH, Fábio. O ideal de Justiça em Aristóteles. Disponível em http://www.ambitojuridico.com.br/site/index.php?n_link=revista_artigos_leitura\&artigo_id= 1613. Acesso em 07/04/2019, às 11:54.
} 
Uma economia de exclusão, em que muitos são alijados do chamado mercado de consumo, não se apresentam aos olhos dos participantes deste mercado como humanos. São meninos de rua, mendigos, pedintes, enfim, pobres, jovens e negros em sua maioria.

Os participantes do mercado não os reconhecem como seres humanos, mas como animais, ou não seres. Eles simplesmente não existem, são ignorados habitualmente. Pessoas passam pela rua e não os ajudam, não os encaram, não Ihes dirigem sequer um olhar, é como se sua presença não fosse notada. Ao pedirem trocados comumente são simplesmente ignorados, como um fantasma recém morto tentando contato com vivos, sem sucesso.

A invisibilidade social, a falta de contato com outros humanos, não permite que sintam qualquer empatia com os participantes do mercado, se relacionando apenas com outros afastados do mercado, também invisíveis. Os excluídos do mercado só são percebidos pelos integrantes do mercado quando explodem com violência contra estes. A violência é a linguagem que os faz serem notados, vistos, agentes e protagonistas de seus próprios dramas.

Por certo, os dois temas aqui abordados se correlacionam intimamente. Só por meio da efetivação dos Direitos Humanos os invisíveis podem deixar essa condição. Sem respeito aos Direitos Humanos e sem uma política governamental efetivamente guiada pelos seus ideais os invisíveis continuarão como fantasmas sociais e a exclusão apenas aumentará, até romper o já desgastado tecido social. 


\section{Bibliografia}

ABBAGNANO, Nicola. Dicionário de Filosofia. Trad.: Alfredo Bosi \& Ivone Castilho Benedetti, ed. Martins Fontes, São Paulo, 2007.

BRASIL. Constituição da República Federativa do Brasil Disponível

em http://www.planalto.gov.br/ccivil 03/Constituicao/Constituica $\underline{\text { o.htm }}$

BRYCH, Fábio. O ideal de Justiça em Aristóteles. Disponível em http://www.ambitojuridico.com.br/site/index.php?n link=revista artigos leitura \&artigo $i d=1613$. Acesso em 07/04/2019, às 11:54.

COMPARATO, Fábio Konder. A Afirmação Histórica dos Direitos Humanos, 5aㅡ edição, ed. Saraiva, São Paulo, 2007.

Declaração de Independência dos Estados Unidos da América. Disponível em http://www.uel.br/pessoal/jneto/gradua/historia/recdida/decla raindepeEUAHISJNeto.pdf.

Meus Dicionários - $\quad$ Disponível em https://www.meusdicionarios.com.br/humano. 